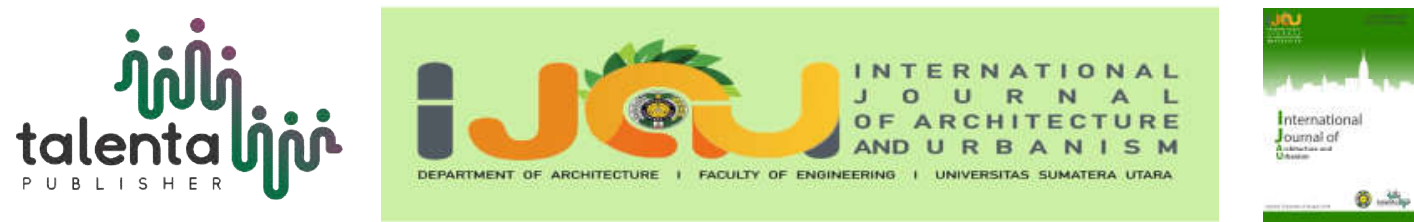

\title{
Flat Rental Housing in Medan Labuhan
}

\author{
Devin Defriza Harisdani ${ }^{1 *}$, Edward Anugrah Zai ${ }^{1}$ \\ ${ }^{I}$ Department of Architecture, Universitas Sumatera Utara, Medan, Indonesia
}

\begin{abstract}
The slum is one of the problems in Medan Labuhan area that is difficult to avoid. One of the causes of a slum settlement in this region is due to the increasingly expensive and limited land that causes low-income people do not have enough purchasing power to live in better areas. In response to this situation, the development of a flat rental housing as called as Rusunawa is one alternative that can be done to meet the needs of the community. With the implementation of the Green Architecture concept, the planned Rental Flat Housing can use the maximum use of natural resources and reduce the negative impact on the environment and can create an effective, comfortable and livable dwelling in Medan Labuhan area.
\end{abstract}

Keyword: housing, green architecture, slum

\section{Introduction}

The slum is one of the problems in Medan Labuhan area that is difficult to avoid, most residential in this area do not have regularity which causes loss of feasibility values in a dwelling. In the procurement of urban housing for low-income people, there are some constrains as follows: financing constraints, availability constraints and land pricing, availability of infrastructure for housing, and constraints on building materials and building codes [1]. One of the causes of slum settlements in this region is due to the increasingly expensive and limited land that causes low-income people do not have enough purchasing power to live in better areas. In response to this situation, the development of flat is one alternative that can be done to meet the needs of people, especially low and middle-income earners to get a chance to have a comfortable dwelling and habitable.

Flat housing with the application of the concept of Green Architecture is an architectural planning approach that can minimize the use of natural resources and reduce the negative impact on the environment. Where it can support in creating a comfortable and livable dwelling. In line with this is also expected to improve the qualities of Medan Labuhan area with the

\footnotetext{
*Corresponding author at: Department of Architecture, Faculty of Engineering, Universitas Sumatera Utara,

Jalan Perpustakaan Gedung J07, Medan 20155, Indonesia

E-mail address: devin.defriza@usu.ac.id
} 
creation of an effective area with a good layout for residents and communities residing in this area.

\section{Literature Review}

Based on the Regulation of the State Minister of Public Housing (PMNPR 2007) ${ }^{1}$ about Management of Simple Flat Rental Housing, Flats are multilevel buildings constructed in an environment divided into structurally functional sections in horizontal and vertical directions and are units which can be owned and used separately, the lease tenancy status and built using the State Budget and / or Regional Revenue and Expenditure Budget with its main function as a dwelling. Based on the Regulation of the Minister of Public Works (PMPU 2007) ${ }^{2}$ regarding the Technical Guidelines for the Development of Low-Size High-Residential Flats, Flat housing is apartment houses designated for low-income people.

Green Architecture is a concept that can minimize the use of natural resources and reduce the negative impact on the environment [2]. The concept of green building refers to the structure and uses environmentally responsible processes and efficient resources during the life cycle of the building: from land to design, construction, operation, maintenance, renovation and demolition [3].

\section{Methodology}

Stages of study in the selection of locations and ideas on the project "Rental Flat Housing In Medan Labuhan" can be described through several stages, namely: Selection of location refers to $\mathrm{RTBL}^{3}$ of Chinatown area of Medan Labuhan 2010-2030, which is based on the structure of the area that the location to be designed is a residential area with an unorganized medium density and then Design ideas by tracing information and data that support both architectural and non-architectural through various libraries and media as a material consideration in solving design problems.

Furthermore, the data analysis is done qualitatively by analyzing the aspect of the activity actors, the space need, spatial and circulation arrangement, then analyzed quantitatively by analyzing the space capacity and the amount of space and the approach to location and site. Here's analysis that affects this design project: Site analysis, function analysis, activity analysis, space analysis, structure analysis.

\footnotetext{
1 PMNPR (Peraturan Menteri Negara Perumahan Rakyat) : Regulation of The State Minister of Public Housing

2 PMPU (Peraturan Menteri Pekerjaan Umum) : : Regulation of The Minister of Public Works

3 RTBL (Rencana Tata Bangunan dan Lingkungan) : Building and Environmental Plans
} 


\section{Result and Discussion}

\section{Programming}

Programming planning and space size are based on data on to $\mathrm{BPS}^{4} 2015$ Medan on the number of families according to sub-district and family classification, where there are 3,722 families with pre-prosperous family classification in Medan Labuhan sub-district. Rental flat housing in Medan Labuhan is aimed at low-income people in the area, where according to Regulation of the Minister of Public Works (PMPU 2007) about Technical Guidance of High Building Simple Flats stated that low-income people are people with income above Rp.1.000. 000, up to Rp.2.500.000, per month, or stipulated by the State Minister of Public Housing. Rental flat housing in Medan Labuhan is assumed to accommodate as many as 336 families or equal to 1,344 people with the planning of one unit of residential towers occupied by two to four people.

\section{Location Choosing}

Site selection refers to the RTBL of Chinatown Medan Labuhan area 2010-2030, which explains that the location to be designed is a residential area with a moderate density that is not well ordered. Based on RTRW ${ }^{5}$ of Medan City 2010-2030, Medan Labuhan area in urban structure serves as a municipal service center in the north, and Pekan Labuhan urban village serves as a transportation service center, social activity center, industrial activity center, security defense center and trade activity center and regional services. Based on RTRW of Medan City 2010-2030, Medan Labuhan sub-district is served by Medan Labuhan sub-center of service, which is part of the northern city service center.

Based on these functions, the design of flats can be an alternative in overcoming the population density, with reference to the requirements of Government Flats and Apartment / Private Flats that have been set on RDTR ${ }^{6}$ Policy of Medan City 2015-2035 namely: DDB $^{7}$ maximum 60\%, $\mathrm{KLB}^{8}$ maximum 10, $\mathrm{KDH}^{9}$ minimum 20\%, Maximum building height 20 floors / 80 meters, Basement maximum $1 / 2$ of road border, Coefficient / calculation of the minimum distance of the building is three meters from the parcel boundary and adjusted the pattern with the existing building border line around the location.

\section{Zoning}

The concept of site zoning is done by considering the relationship between outer space and inner space, both from private and public areas connected to each other so that residents can feel

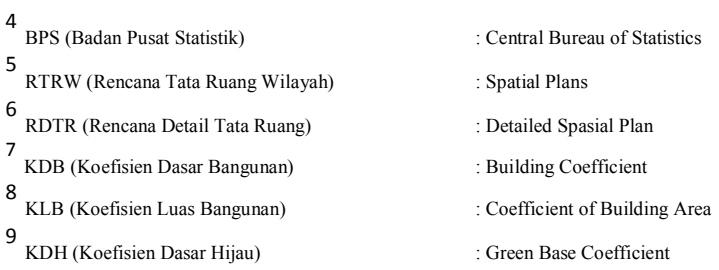


comfortable in both residential and public areas. The site is also designed to connect with the heritage area (Figure 1).

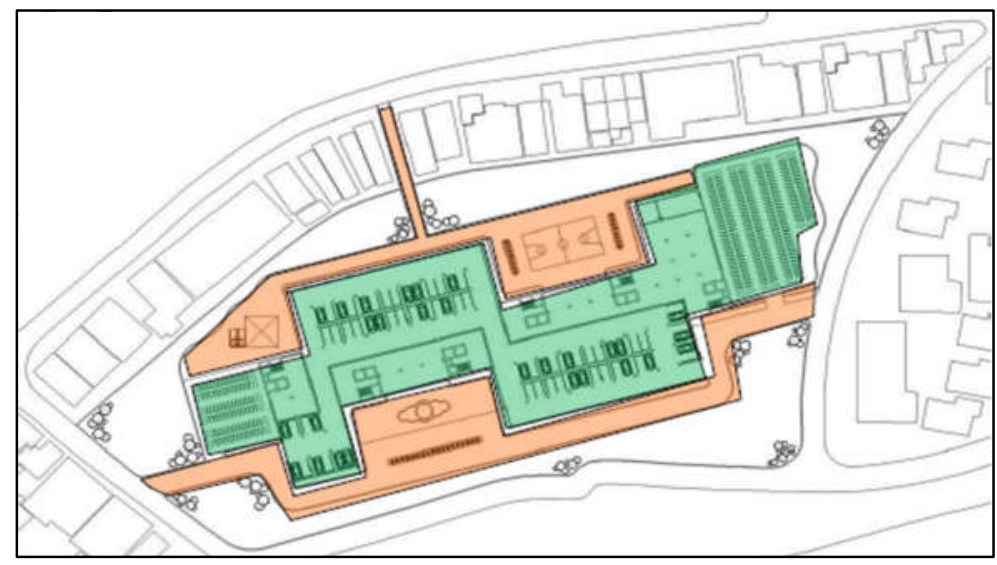

Figure 1. Zoning on Site

\section{Circulation and An Organization of Vertical / Horizontal Space}

Circulation in this rental apartment using Central Corridor System or also called double loaded system is a corridor system that serves residential units of two sides. On the side of the corridor and occupancy, there is a void as a separator between semi-public and private zone as well as air circulation in buildings. As for the vertical circulation, in each tower, there are four units of an elevator, one emergency lift, and two fire stairs (Figure 2). There are two alternative occupancy type 36 in this building. Type 36A which has two bedrooms and type $36 \mathrm{~B}$ which has one bedroom but has free space that can be utilized as needed (Figure 3).

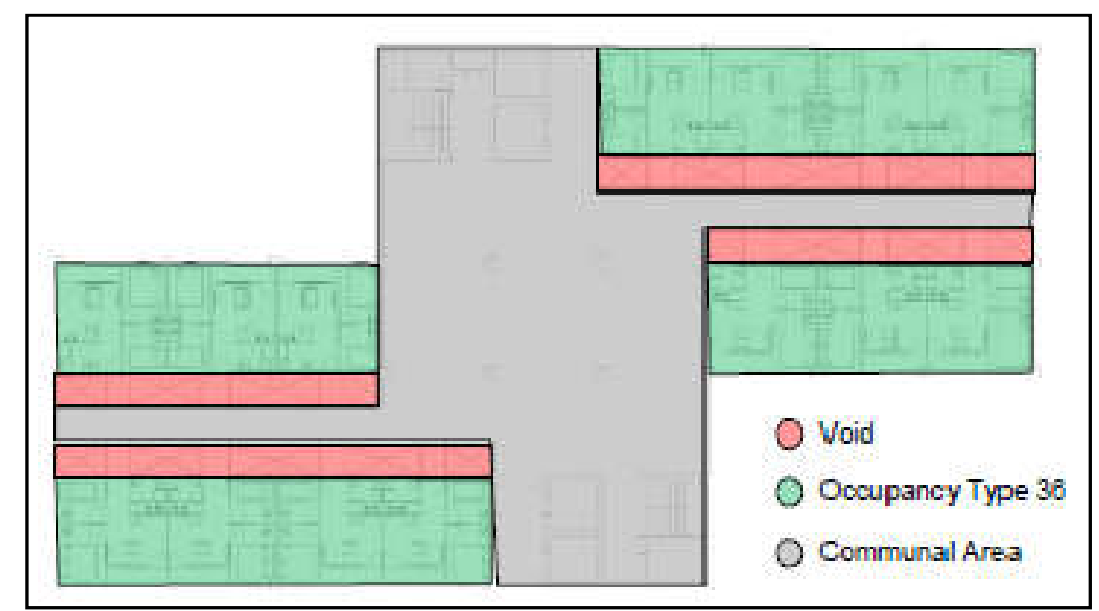

Figure 2. Circulation on 3rd - 10th floor 


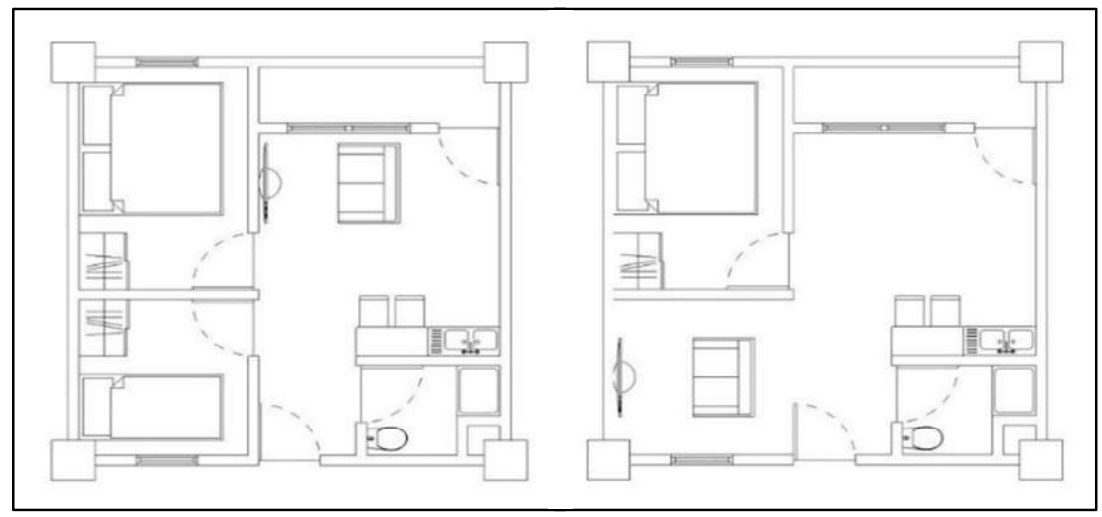

Figure 3. Occupancy Type 36A and Type 36B

\section{Modelling Concept and Display}

The concept of mass planning and building display will use precast concrete with an emphasis on function and efficiency in the design by the standardization of high-rise apartment development. The building will be designed with green architecture concept applied to green space and green roof on roof top floor of the building (Figure 4). The atmosphere of the basketball court that serves as a gathering place for residents (Figure 5). Building perspective and green space atmosphere on the $2^{\text {nd }}$ floor of the building (Figure 6).

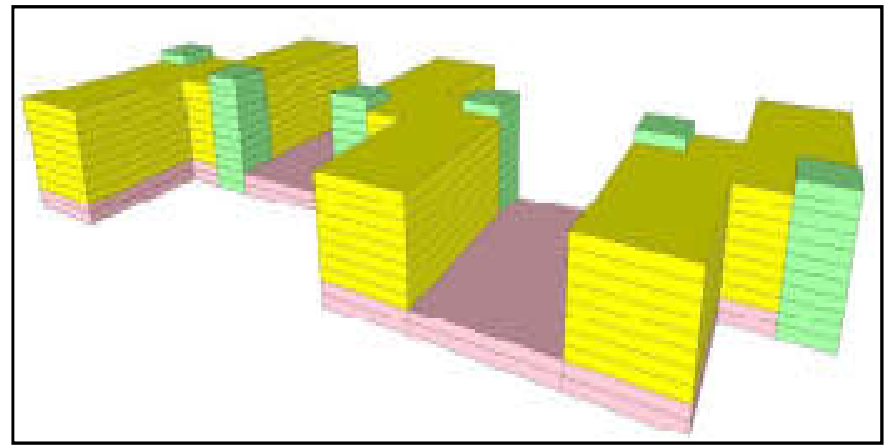

Figure 4. Modelling Concept

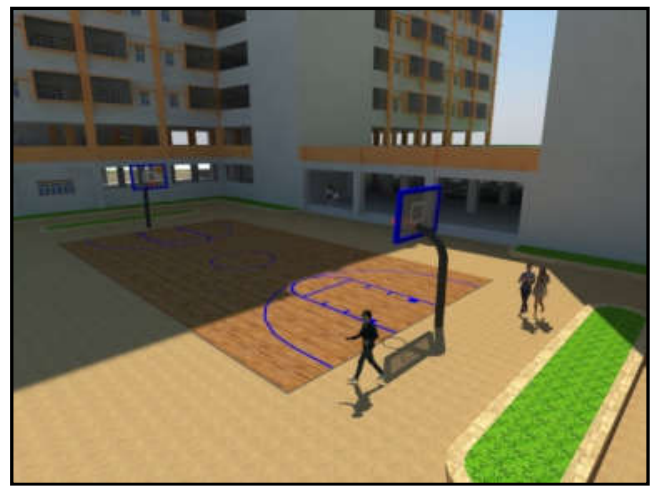

Figure 5. Basketball Court 


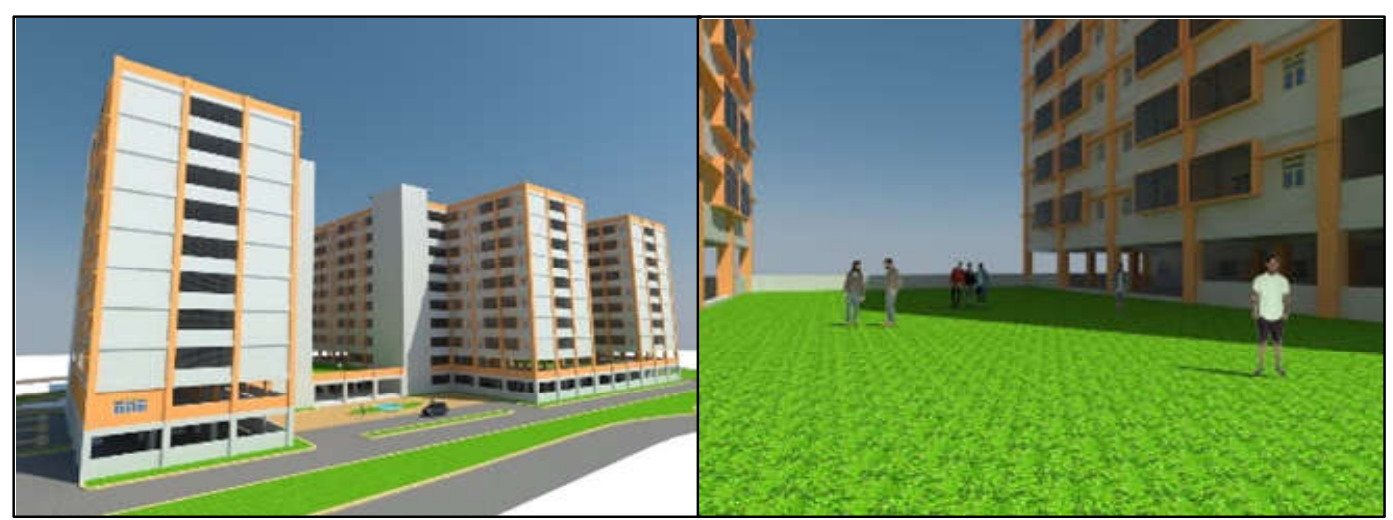

Figure 6. Building Perspective and Green Space

\section{Structural Concept / Construction System}

The main structure system in this building combines core and rigid frame, as well as for the foundation using bore pile. On the podium floor, there is a dilation against the tower for separation and maintaining structural stability. Size of the column used is $60 x 60$ with span width six meters. For the main beam ring use size $60 \times 40$ and ring beam of fellow use size $30 \times 20$. The construction system uses the precast system because it is better in quality and speed of development and more economical compared with the conventional system. For the outer wall using precast concrete while the barrier wall using lightweight concrete, so the load structure will be lighter. On the rooster and void of the building will be designed iron bars as a safety (Figure 7).

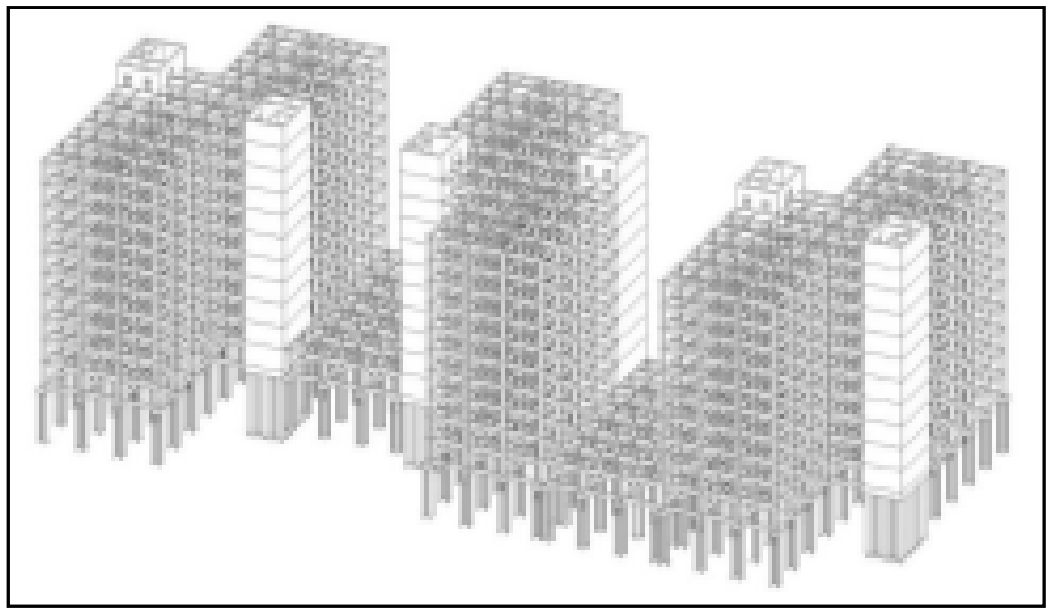

Figure 7. Structural Concept/Construction System

\section{Utility System Concept}

Application of Green Architecture concept in this apartment building applied to the utility of building, which is with green space design on the second floor of building and green roof at third occupancy tower. It serves as a gathering place for residents and as a rain water shelter that 
will be flowed to the ground water tank and then can be reused for the needs of residents (Figure $8)$.

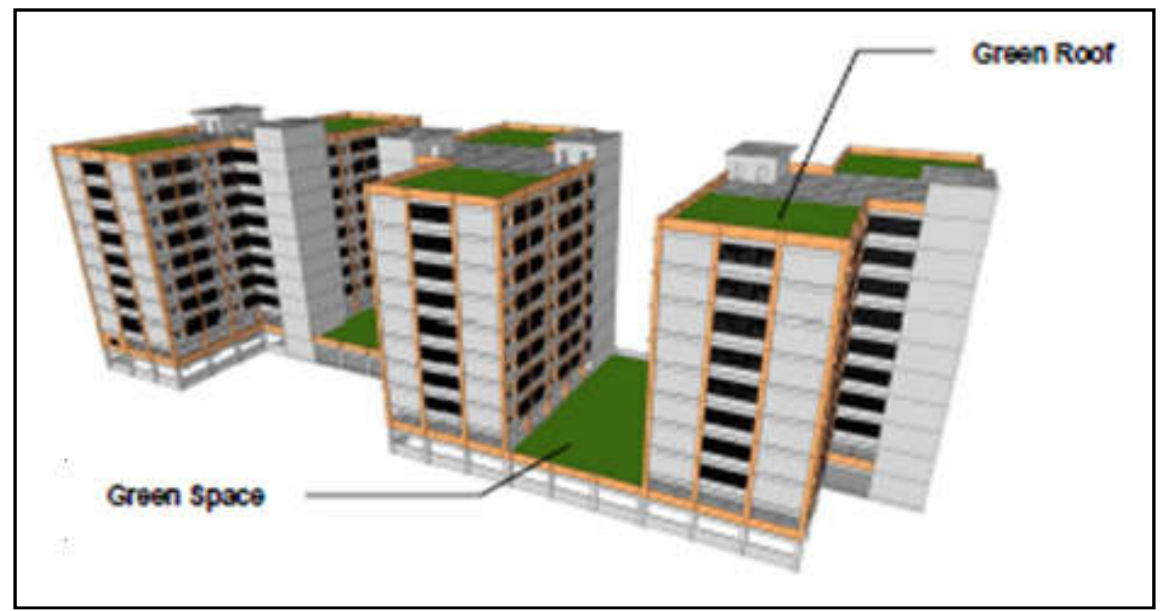

Figure 8. Utility System Concept

\section{Conclusion}

The conclusion of the design of Rusunawa Medan Labuhan is that a simple high-rise flat building is a solution of slum settlement problems in Medan Labuhan area. Rental flat housing is intended for people especially low-income people to have a more decent and comfortable dwelling. With the implementation of the concept of Green Architecture in this flat building can support in creating a comfortable residential area and effectively with good spatial for residents and the people who are in the surrounding area to improve the quality of Medan Labuhan area.

\section{Acknowledgment}

This research is part of the requirement to obtain a bachelor's degree in the Architecture Department of Universitas Sumatera Utara.

\section{REFERENCES}

[1] B. Panudju. Pengadaan Perumahan Kota dengan Peran Serta Masyarakat Berpenghasilan Rendah. Alumni. 1999.

[2] T. H. Karyono. Green Architecture: Pengantar pemahaman arsitektur hijau di Indonesia. Rajawali Pers. 2010.

[3] M. M. Sudarwani. Penerapan Green Architecture dan Green Building sebagai upaya pencapaian sustainable Architecture. Dinamika Sains, 10 (24). 2012. 